\title{
EFFECT OF THERMAL PROCESSING ON ANTIBACTERIAL ACTIVITY OF MULTIFLORAL HONEYS
}

\author{
D.J. PIMENTEL-GONZÁLEZ1', U.A. BASILIO-CORTES' ${ }^{1}$, A.D. HERNÁNDEZ-FUENTES ${ }^{1}$, A.C. FIGUEIRA², \\ A. QUINTERO-LIRA ${ }^{1}$ and R.G. CAMPOS-MONTIEL $L^{1,3}$ \\ ${ }^{1}$ Instituto de Ciencias Agropecuarias, Universidad Autónoma del Estado de Hidalgo, Av. Rancho Universitario s/n Km. 1. Tulancingo, Hidalgo, C.P. \\ 43600, México \\ ${ }^{2} \mathrm{CIEO}$, Centro de Investigação sobre o Espaço e Organizações e Departamento de Engenharia Alimentar, Universidade do Algarve, Faro, Portugal
}

${ }^{3}$ Corresponding author.

TEL: 52-7717172000 ext. 2421;

FAX: 52-7717172000 ext. 2422;

EMAIL: ragcamposm@gmail.com

Received for Publication May 12, 2015

Accepted for Publication August 3, 2015

doi:10.1111/jfpe. 12279

\begin{abstract}
In this study, the effects of thermal processing in the antibacterial activity of four multifloral honeys were determined. The thermal treatments were carried out at $30,40,50,60,70$ and $80 \mathrm{C}$, and the following characteristics were determined: total phenols and antibacterial activity of three gram-positive bacteria (Bacillus subtilis, Staphylococcus aureus and Listeria monocytogenes) and three gram-negative bacteria (Escherichia coli, Salmonella typhimurium and Pseudomonas aeruginosa). The results showed that the behavior of total phenols in relation to temperature depended on the floral sources of honey. The honeys presented curves of either linear or quadratic responses of the antibacterial activity in relation to the thermal process, depending on the honey's floral sources and the kind of bacterium to inhibit. The results suggest that the honey's antibacterial activities and behavior with the temperature are different depending on the honey's floral sources and the kind of bacteria that they inhibit.
\end{abstract}

\section{PRACTICAL APPLICATIONS}

The consumer trend to search for minimally processed foods has increased in recent years due to the perception that food processing decreases its health benefits and antibacterial activities. Honey can inhibit pathogenic bacteria, but this inhibition is determined by the floral source from which the honey is collected. In this study, it was shown that thermal processing has a different effect on the antibacterial activities of each honey. These effects were linear or quadratic according to the bacteria (Bacillus subtilis, Staphylococcus aureus, Listeria monocytogenes, Escherichia coli, Salmonella typhimurium and Pseudomonas aeruginosa) and the floral source of the honey. This effect did not depend on the Gram (the inhibition against Salmonella typhimurium was linear with respect to the thermal process in all honey), in contrast to E. coli (where the effect was quadratic with a peak at $60 \mathrm{C}$ in all of the honey). The results led to the conclusion that the thermal processing of each honey must be different to maximize their beneficial health effects as well as their antibacterial activities.

\section{INTRODUCTION}

Honey is a natural food produced by bees (Apis mellifera) from the nectar extracted from a variety of plants. Many types of foods have beneficial effects on human health (Campos-Montiel etal. 2013), and particularly plant extracts contain polyphenols and anthocyanins that have beneficial antimicrobial activity (Jimenez et al. 2011). Many constituents of honey are bioactive and carry significant nutritional benefits (Vaikousi et al. 2009; Ajibola et al. 2012). In general, bees collect plant nectar containing bioactive compounds that are subsequently transferred to honey (Baltrušaitytè et al. 2007). However, in addition to the beneficial effects of floral sources of honey, the 
composition of manufactured honey is also influenced by environmental factors and processing (Alvarez-Suarez et al. 2010b). Undiluted honey has an acidic $\mathrm{pH}$ that functions as a significant antibacterial factor (Mandal and Mandal 2011). A strong correlation exists between the bacterial inhibitory capacity and polyphenol content in honey (Tenore et al. 2012). Rubus honey samples contain hydrogen peroxide, phenolic compounds and volatile compounds, and when the antibacterial properties of the samples were assessed with several gram-positive and gramnegative bacteria, the gram-positive bacteria were shown to be the most resistant (Escuredo et al. 2012). Another study showed that saline extracts of 50 and $75 \%$ Rhododendron honey had different resistance responses for gram-positive and gram-negative bacteria (Silici et al. 2010).

Normally, honey is subjected to thermal treatment. The industrial manufacture of honey includes two stages: the liquefaction process (performed at approximately 55C) and the pasteurization process (performed at approximately 80C) (Escriche et al. 2008). The effects of industrial thermal treatment on flavonoids and phenolic compounds are influenced by the type of honey being processed (Escriche et al. 2014). Kowalski (2013) reported that the effects of conventional heating and microwave processing on the total phenolic compounds and antioxidant activity depend on the botanical origin of honey. Cui et al. (2008) reported that the preparation of dry honey by microwave vacuum drying decreases the acidity and increases the aldehyde and ketone content. Furthermore, increases in the processing temperature of eucalyptus honey lead to a decrease in antifungal activity against Candida albicans (Moussa et al. 2012).

The change in physicochemical properties due to highprocessing temperatures might also affect the antibacterial activity of honey. This study aims to determine the effects of the processing temperature of honey from Hidalgo, Mexico, on total phenolic content and on the antibacterial activities against several gram-positive and gram-negative bacteria.

\section{MATERIALS AND METHODS}

\section{Sample Collection}

Four samples of multifloral honey originating in different geographic regions of the State of Hidalgo, Mexico, were used: Acaxochitlán (fruit and Graminacea), Arenal (complex flowers), Huehuetla (Rubiaceae) and Tasquillo (Junglas). These honey samples were analyzed microscopically to determine the frequency and the classes of pollen (Erdtman 1960). A mass of 1,500 g of each sample was collected in sterile containers that each contained $500 \mathrm{~g}$ each. The contained samples were packed and sealed in amber glass bottles and stored at 5C in the dark until testing.

\section{Heating Procedure}

The honey samples were subjected to heating in a water bath at temperatures of $40,50,60,70$ and $80^{\circ} \mathrm{C}$. This procedure involved place $100 \mathrm{~g}$ of honey samples (85\% concentration the honey for microbiological assays and 100\% concentration for phenolic content) in glass jars which were placed in the water bath with constant agitation for 45 minutes at the appropriate temperature. The samples were subsequently left in the dark to return to room temperature.

\section{Total Phenolic Content}

The phenolic content of heat-treated honey samples was assessed using the Folin-Ciocalteu method described by Singleton et al. (1999). Five grams of the sample was diluted to $50 \mathrm{~mL}$ distilled water and filtered through a Whatman no. 1 filter paper. A volume of $0.3 \mathrm{~mL}$ of solution was then mixed with $1.5 \mathrm{~mL}$ of $0.2 \mathrm{~N}$ Folin-Ciocalteu reagent (Sigma-Aldrich, St Louis, MO, USA) for $5 \mathrm{~min}$ and then further homogenized with $1.2 \mathrm{~mL}$ of $\mathrm{Na}_{2} \mathrm{CO}_{3}(0.7 \mathrm{M})$. The resulting mixture was measured at $765 \mathrm{~nm}$ against a blank solution using a spectrophotometer. The total phenolic content was determined by constructing a standard curve using gallic acid (Sigma-Aldrich, St Louis, MO, USA) standard solutions with a range of $0-200 \mathrm{mg} / \mathrm{L}$. The total phenol amount was expressed in mg of gallic acid equivalents/100 g of honey.

\section{Antibacterial Assay}

Six bacterial strains were used in total. The three grampositive strains were Bacillus subtilis (ATCC 6630), Staphylococcus aureus (ATCC 13709) and Listeria monocytogenes (ATCC 15313). The three gram-negative strains were Escherichia coli (ATCC 25922), Salmonella typhimurium (ATCC 43971) and Pseudomonas aeruginosa (ATCC 27853).

Nutrient broth was used for the activation of each microorganism. All bacteria were incubated at 37C; E. coli was left to incubate for $5 \mathrm{~h}$, S. aureus for $9 \mathrm{~h}$, S. typhimurium for 22.5 h; B. subtilis, P. aeruginosa and L. monocytogenes were incubated for $24 \mathrm{~h}$ to obtain a $10^{6}-10^{7}$ colony-forming unit (cfu)/mL concentration.

All honey samples were diluted in physiological solution for three solutions with final concentrations of 55, 70 and $85 \%$. One milliliter of a suspension of $10^{6} \mathrm{cfu} / \mathrm{mL}$ was added to each of the $9 \mathrm{~mL}$ honey dilutions. Media of specific growth agar eosin methylene blue were prepared for the E. coli; for S. aureus the media was used an agar of Staphylococcus aureus; S. typhimurium used agar of Salmonella and Shigella whereas B. subtilis, L. monocytogenes and $P$. aeruginosa used nutrient agar. Honey-bacteria suspensions were added to the plates and incubated for $24 \mathrm{~h}$ at 
TABLE 1. EFFECT OF TEMPERATURE ON TOTAL PHENOL CONTENT OF SEVERAL MULTIFLORAL HONEY SAMPLES

\begin{tabular}{|c|c|c|c|c|c|c|}
\hline \multirow[b]{2}{*}{ Sample } & \multicolumn{6}{|c|}{ Total phenols mg gallic acid/100 g } \\
\hline & $20 C$ & $40 C$ & $50 C$ & $60 C$ & $70 C$ & $80 C$ \\
\hline Acaxochitlán & $91.74 \pm 0.7^{\mathrm{Ca}}$ & $92.73 \pm 0.5^{c a}$ & $93.05 \pm 0.61^{\mathrm{Ca}}$ & $93.36 \pm 0.72^{\mathrm{ca}}$ & $95.66 \pm 0.2^{\mathrm{Ba}}$ & $97.95 \pm 0.7^{\mathrm{Ab}}$ \\
\hline Arenal & $42.08 \pm 0.17^{\mathrm{Eb}}$ & $42.92 \pm 1.8^{\mathrm{Db}}$ & $44.71 \pm 1.17^{\mathrm{cb}}$ & $46.49 \pm 0.57^{\mathrm{Bb}}$ & $47.31 \pm 0.2^{\mathrm{Ab}}$ & $48.12 \pm 0.2^{\mathrm{Ad}}$ \\
\hline Tasquillo & $154.54 \pm 1.2^{\mathrm{Da}}$ & $154.95 \pm 0.4^{\mathrm{Da}}$ & $161.33 \pm 0.28^{\mathrm{Ca}}$ & $167.71 \pm 0.23^{\mathrm{Aa}}$ & $164.58 \pm 0.6^{\mathrm{Ba}}$ & $161.44 \pm 1.1^{\mathrm{Ca}}$ \\
\hline Huehuetla & $53.86 \pm 0.7^{\mathrm{Ba}}$ & $53.74 \pm 0.5^{\mathrm{Ba}}$ & $55.45 \pm 0.71^{\mathrm{ABa}}$ & $57.17 \pm 0.99^{\mathrm{Aa}}$ & $56.29 \pm 0.4^{\mathrm{Aa}}$ & $55.41 \pm 0.67^{A B C}$ \\
\hline
\end{tabular}

Different uppercase letters represent significant differences $(P<0.05)$ between measured temperatures determined by Tukey's comparison of averages. Different lowercase letters represent significant differences $(P<0.05)$ between honey samples determined by Tukey's comparison of averages. Honey samples were treated at the following temperatures: 20, 40, 50, 60, 70 and $80 \mathrm{C}$.

37C, followed by the determined cell counts for $\mathrm{cfu} / \mathrm{mL}$. As a negative control, plates were incubated with a sterile saline solution and as a positive control ciprofloxacin was used.

\section{Statistical Analysis}

The experiments were performed in triplicate. The experimental design was completely randomized when there were significant differences $(P<0.05)$ using Tukey's test $(P<0.05)$ or orthogonal comparison to determine the nature of the response curves. The correlation between total phenols and antibacterial activity was determined. All data were analyzed using the NCSS 2007 sofware (Wireframe Graphics, Kaysville, UT).

\section{RESULTS}

Table 1 shows that the total phenol concentration is affected by the treatment temperature of honey and that there are significant differences $(P<0.05)$ between the particular type of honey and the effects from a given treatment temperature. The Acaxochitlán and Arenal honey samples showed markedly different behavior from the Tasquillo and Huehuetla honey samples. The Tasquillo and Huehuetla samples showed that the highest concentration of total phenols was obtained when treated at a temperature of 60C. The Acaxochitlán and Arenal samples, in contrast, showed that the highest concentration of total phenols was obtained at a temperature of $80 \mathrm{C}$.

The antibacterial activity results for the gram-positive bacteria are shown in Table 2. All honey samples showed antibacterial activity against $B$. subtilis, although significant differences were found $(P<0.05)$ among the antibacterial qualities of the types of honeys. Significant differences $(P<0.05)$ in antibacterial activity toward L. monocytogenes were found based on honey type and honey concentration. Less than $90 \%$ inhibition was observed in all types of honey at a concentration of $85 \%$, with Arenal honey showing the highest antibacterial activity (Table 2). Acaxochitlán honey at a concentration of $85 \%$ showed the highest antibacterial activity toward S. aureus (with $70.45 \%$ inhibition, $P<0.05$ ) (Table 2).

The antibacterial activities toward gram-negative bacteria are shown on Table 3. All honey samples had bactericidal activity toward S. typhimurium from the lowest tested honey concentration of 55\%. However, the types and concentrations of the honey samples showed significantly different $(P<0.05)$ antibacterial activities. P. aeruginosa was the most resistant bacterium, and at concentrations of 55 and $70 \%$ antibacterial activities below $61.22 \%$ were obtained. Significant differences $(P<0.05)$ were found among honey types. The honey from Acaxochitlán had the highest antibacterial activity (Table 3 ). Significant differences $(P<0.05)$ in antibacterial activity toward $E$. coli were observed among different honey types at all tested concentrations (55, 70 and 85\%). Tasquillo honey demonstrated the highest antibacterial activity of all honey samples toward E. coli, with an inhibitory percentage of $93.63 \%$ at a concentration of $85 \%$.

Gram-positive and gram-negative bacteria did not show distinct trends in tested characteristics measured in this work (Tables 2 and 3).

The effects of treatment temperature on honey samples' antibacterial activity toward gram-positive bacteria are shown in Fig. 1. A linear relationship was observed between treatment temperature and antibacterial activity toward B. subtilis for Arenal, Huehuetla and Tasquillo honey samples (Fig. 1a), while Acaxochitlán honey showed a quadratic relationship between treatment temperature and B. subtilis antibacterial activity with maximum antibacterial activity at $60 \mathrm{C}$. Regarding antibacterial activity toward L. monocytogenes (Fig. 1b), a quadratic response curve with a maximum at 60C was observed for Acaxochitlán, Arenal and Huehuetla honey samples. However, a linear response was observed from Tasquillo honey toward L. monocytogenes. A quadratic relationship between treatment temperature and antibacterial activity toward $S$. aureus was observed for all honey samples tested (Fig. 1c).

The results showing the antibacterial activity toward tested gram-negative bacteria by the honey samples are 

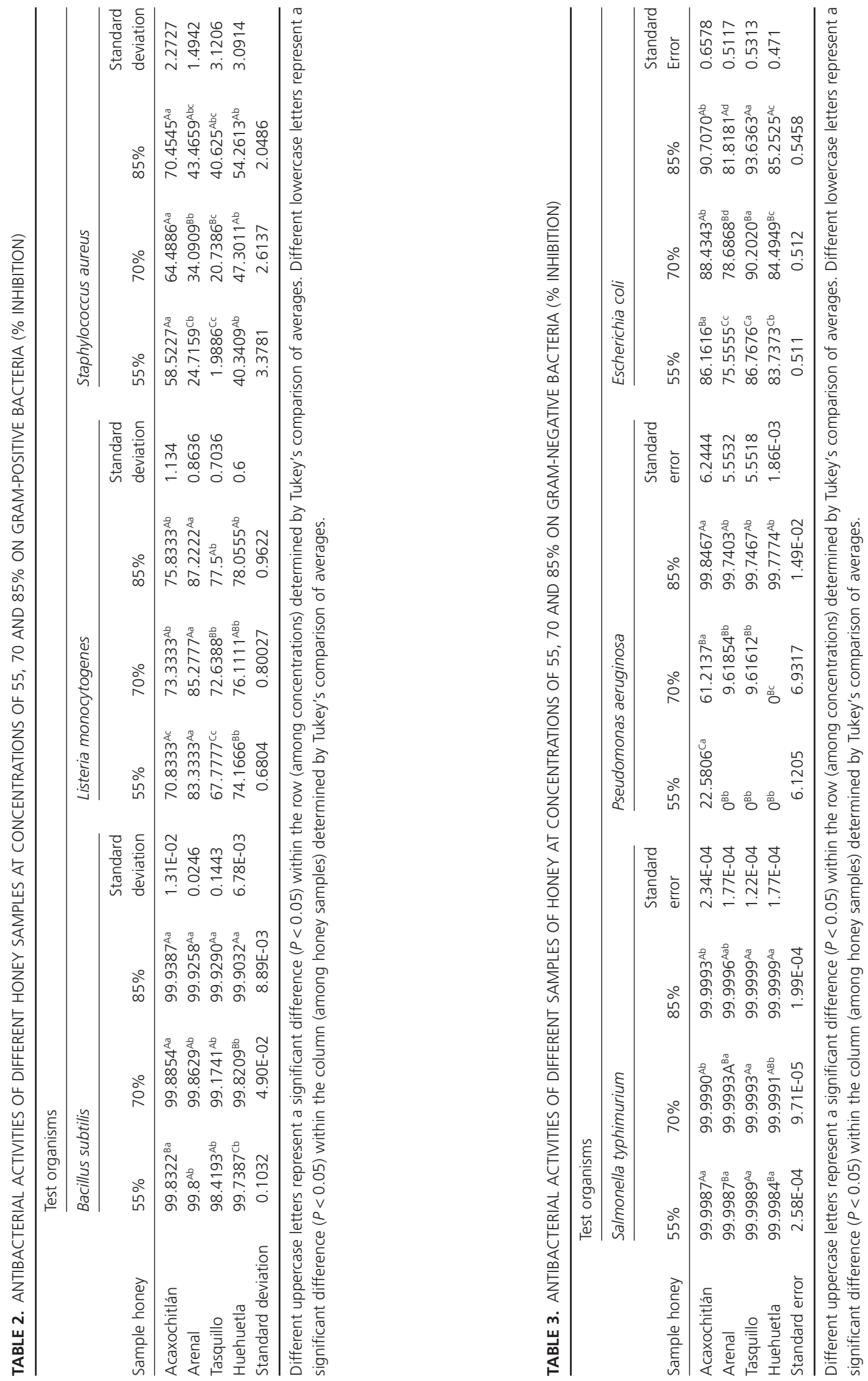

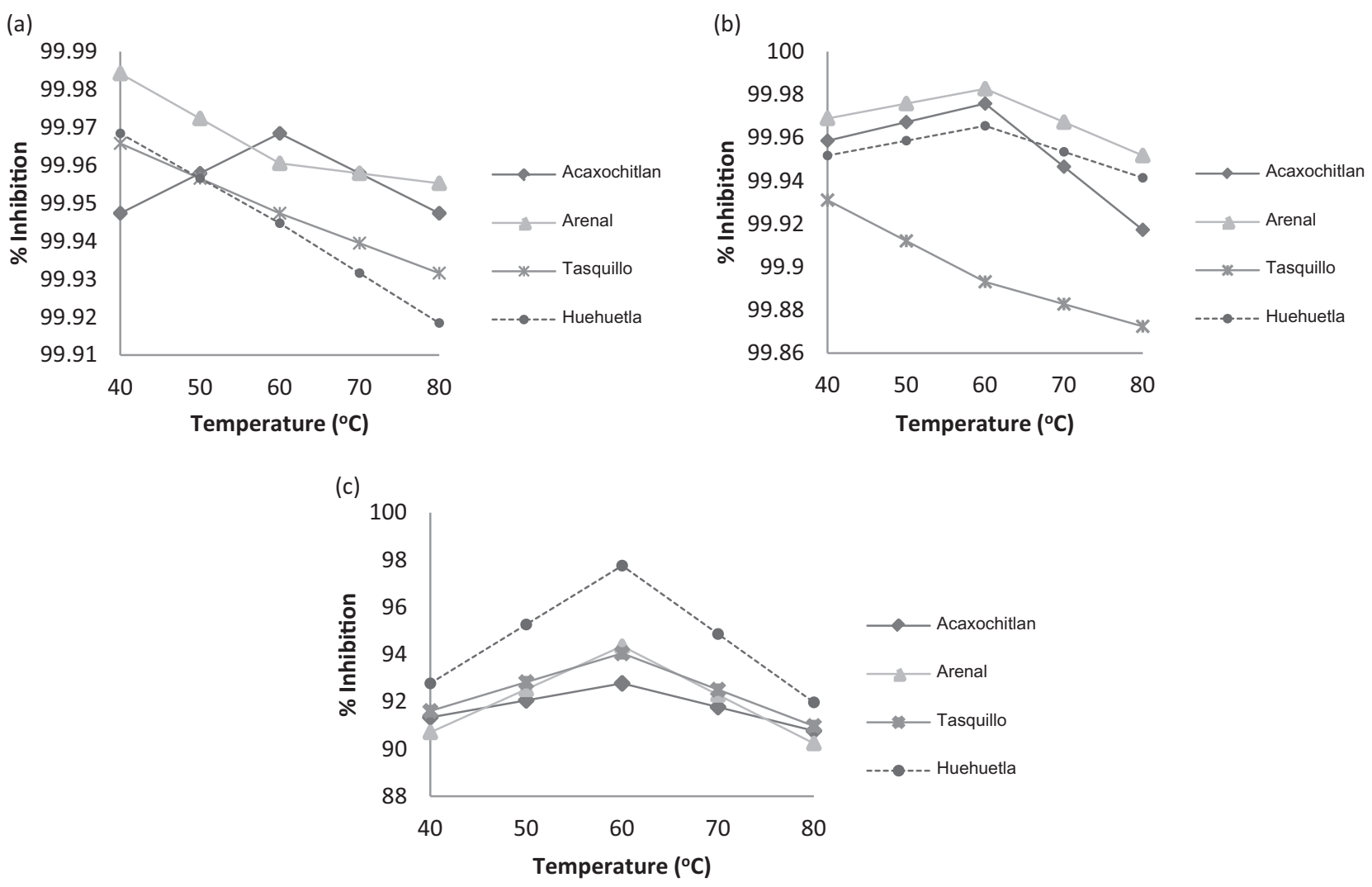

FIG. 1. INHIBITION OF THE GROWTH OF (A) BACILLUS SUBTILIS, (B) LISTERIA MONOCYTOGENES AND (C) STAPHYLOCOCCUS AUREUS DUE TO ANTIBACTERIAL ACTIVITIES OF MULTIFLORAL HONEY SAMPLES FROM GEOGRAPHICAL REGIONS THROUGHOUT THE STATE OF HIDALGO THAT HAVE BEEN TREATED AT THE FOLLOWING TEMPERATURES: 40, 50, 60, 70 AND $80 \mathrm{C}$

shown in Fig. 2. All honey samples showed negative linear response curves for S. typhimurium (Fig. 2a), in which increases in treatment temperature resulted in decreases in antibacterial activity. Linear response curves were observed in Arenal, Tasquillo and Huehuetla honey samples toward P. aeruginosa (Fig. $2 \mathrm{~b}$ ), although a quadratic response curve was observed for the Acaxochitlán honey sample. Quadratic response curves with maxima at $60 \mathrm{C}$ were found to relate E. coli antibacterial activity to treatment temperature for all honey samples (Fig. 2c).

Only antibacterial activity toward S. typhimurium was linearly correlated to the total phenol content in all honey samples investigated with correlation coefficients ranging from $r=0.7849$ to $r=0.9642$ (Table 4). In contrast, the percentage of inhibition of E. coli was only linearly correlated to total phenol content in the Acaxochitlán honey sample, which had a correlation coefficient of $r=0.8896$.

\section{DISCUSSION}

Our results relating thermal processing to the total phenol concentration in honey are similar to those reported by
Kowalski (2013), who showed that the relationship between phenol concentration and thermal or microwave treatment depends on the origin of the honey. Escriche et al. (2014) reported that the variation in intrinsic properties of honey is more strongly dependent on the honey origin than on the conditions used for liquefaction and pasteurization. This report is supported by results shown in Table 1 , in which the highest total phenol content is consistently observed in Tasquillo honey regardless of the treatment temperature. Fujita et al. (2013), however, reported a decrease in the total phenol content upon drying of Myrciaria dubia pulp in treatment temperatures between 60 and 110C. Similarly, Sagrin and Chong (2013) observed that the total phenol content decreases with treatments at temperatures between 40 and 60C during the drying process for Musa acuminata.

All tested honey samples in this study showed inhibitory effects on gram-positive bacteria. Our results regarding B. subtilis are similar to those reported by Silici et al. (2010), which showed that $B$. subtilis is inhibited by honey samples collected from different regions of Turkey when present at concentrations of 50 and $75 \%$. Similar results were also found by Alvarez-Suarez et al. (2010a), who reported that 
(a)

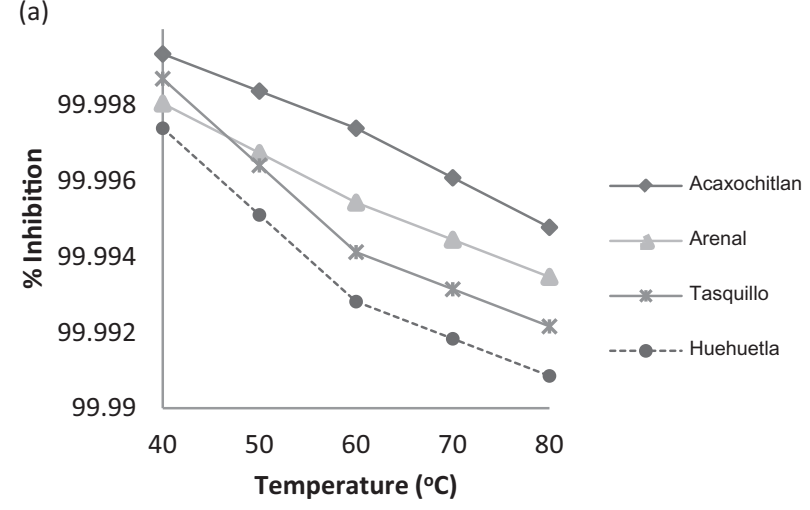

(b)

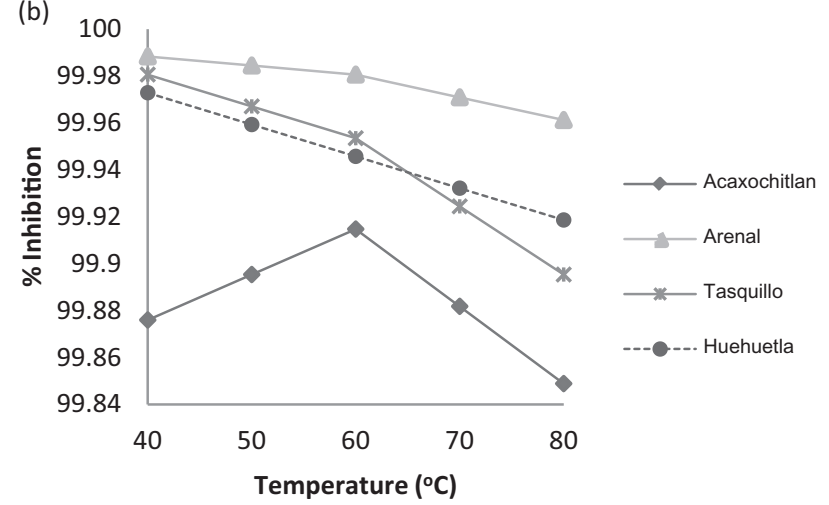

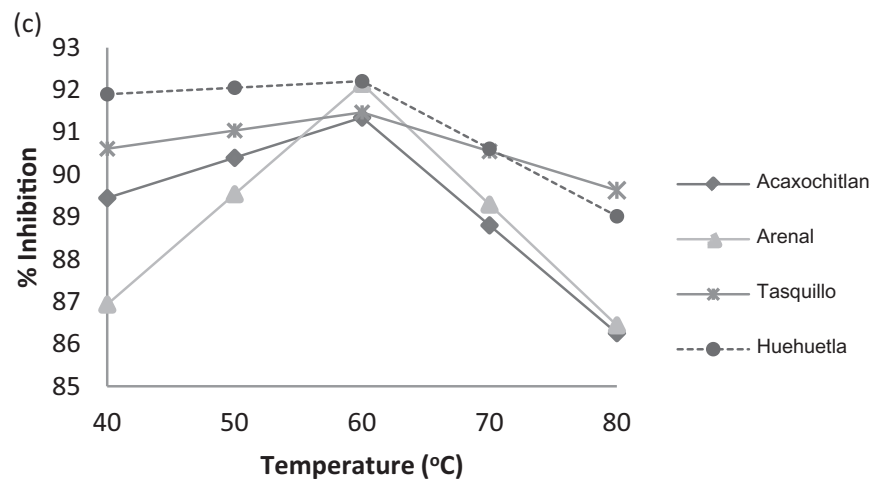

FIG. 2. INHIBITION OF THE GROWTH OF (A) SALMONELLA TYPHIMURIUM, (B) PSEUDOMONAS AERUGINOSA AND (C) ESCHERICHIA COLI DUE TO ANTIBACTERIAL ACTIVITIES OF MULTIFLORAL HONEY SAMPLES FROM GEOGRAPHICAL REGIONS THROUGHOUT THE STATE OF HIDALGO THAT HAVE BEEN TREATED AT THE FOLLOWING TEMPERATURES: 40, 50, 60, 70 AND $80 C$

B. subtilis showed the highest sensitivity to honey. Inhibition results for L. monocytogenes are similar to those from a previous report in which the bacterium was inhibited at a honey concentration of 75\% (Silici et al. 2010). Antibacterial activity was less prominent for $S$. aureus, a result that is supported by Abril and Ramirez (2009) and Silici et al. (2010), who reported lower inhibition of S. aureus by honey collected from various regions of Colombia and Turkey.

In our study, all honey samples inhibited the growth of gram-negative bacteria. Bactericidal activity was observed

\begin{tabular}{|c|c|c|c|}
\hline \multirow[b]{3}{*}{ Honey sample } & \multicolumn{3}{|l|}{ Gram+ } \\
\hline & Bacillus subtilis & Listeria monocytogenes & Staphylococcus aureus \\
\hline & \multicolumn{3}{|c|}{ Total phenols (mg gallic acid/100 g honey) } \\
\hline Acaxochitlán & 0.08554 & 0.49918 & 0.45698 \\
\hline Arenal & 0.11523 & 0.64028 & 0.64388 \\
\hline Tasquillo & 0.07595 & 0.58258 & 0.61171 \\
\hline \multirow[t]{3}{*}{ Huehuetla } & 0.06126 & 0.53359 & 0.6095 \\
\hline & \multicolumn{3}{|l|}{ Gram- } \\
\hline & Salmonella typhimurium & Pseudomonas aeruginosa & Escherichia coli \\
\hline Honey sample & \multicolumn{3}{|c|}{ Total phenols (mg gallic acid/100 g honey) } \\
\hline Acaxochitlán & 0.96426 & 0.24972 & 0.88968 \\
\hline Arenal & 0.98805 & 0.56679 & 0.57187 \\
\hline Tasquillo & 0.81236 & 0.4374 & 0.38017 \\
\hline Huehuetla & 0.78499 & 0.39558 & 0.48538 \\
\hline
\end{tabular}

TABLE 4. CORRELATION $(R)$ OF TOTAL PHENOL CONTENT AND THE ANTIBACTERIAL ACTIVITY OF DIFFERENT HONEY SAMPLES AGAINST GRAM-POSITIVE AND GRAM-NEGATIVE BACTERIA 
for S. typhimurium, similar to the case described by Abril and Ramirez (2009) that showed that honey from Colombia affects Salmonella at dilutions of 90\%. Our results regarding $P$. aeruginosa agree with those reported by Alvarez-Suarez et al. (2010a) and Estevinho et al. (2008), which show that $P$. aeruginosa exhibited high resistance to the antibacterial activities of various types of honey. The results concerning E. coli are similar to those reported by Voidarou et al. (2011), which showed that different Greek honey samples varied in the inhibitory effects on E. coli.

We did not observe any antibacterial trends based on gram positivity or negativity, a result that is supported by reports from Escuredo et al. (2012), in which antibacterial activity depended on the type of bacterium rather than Gram staining. However, these observations contrast with other reports suggesting that gram-positive bacteria are more sensitive to the antibacterial effects of honey than gram-negative bacteria (Estevinho et al. 2008; Alvarez-Suarez et al. 2010a; Isla et al. 2011; Tenore et al. 2012). These differences could be due to the origins of honey samples and the content of their bioactive compounds, as suggested by Taormina et al. (2001). These authors found that pathogenic bacteria exhibit different levels of sensitivity depending on the type of honey under investigation.

The temperature effects on bacteria (e.g., B. subtilis, L. monocytogenes and P. aeruginosa) suggest that antibacterial properties depend on the particular type and origin of the honey and the linear or quadratic nature of the response curve. According to Taormina et al. (2001), the antibacterial compounds depend on the origin of honey; however, it is possible that certain basic components of honey are responsible for the antibacterial effects on bacteria such as S. aureus, S. typhimurium and E. coli and that the diverse effects on different types of bacteria depend on the biological components present in the particular bacterium. Consequently, S. aureus and E. coli may reasonably display a quadratic response while S. typhimurium shows a linear response curve.

The observed quadratic responses exhibited by some honey samples might be due to the presence of an inhibitory factor such as oxygen peroxide, which is potentially destroyed in the presence of catalase (Mandal and Mandal 2011).

The results obtained regarding the relationship between bacterial growth inhibition and honey temperature treatment (Fig. 2b) show that the Acaxochitlán honey sample has certain behavior that is distinct from the other tested samples. The effects of temperature on the antibacterial activities of honey originating in the State of Hidalgo are comparable with the depletion of antibacterial activity resulting from thermal treatment of wine (Boban et al. 2010). Similar results reported by Moussa et al. (2012) dem- onstrate that inhibitory potency against C. albicans by eucalyptus honey decreased when the temperature increased. Fujita etal. (2013) reported that heating the pulp of My. dubia to $60 \mathrm{C}$ diminished the antibacterial activity toward S. aureus.

The relationship between phenol content in all honey samples and antibacterial effects on S. typhimurium, along with the effect of phenol content in the Acaxochitlán honey sample on inhibition of E. coli, demonstrated that the total phenol content in these honey samples contributed to the inhibition of the corresponding bacteria. These results agree with those of Isla et al. (2011), which demonstrate a correlation between phenol content and antibacterial activity. However, all other bacteria presented low correlation coefficients. Ulusoy et al. (2010) reported that no correlation exists between antimicrobial activity and total phenolic content. This suggestion is consistent with the possibility that these honey samples have nonphenolic bioactive compounds that have different effects depending on the particular bacterium. These observations agree with the report from Silici et al. (2010), in which the total phenolic content is only partially responsible for antibacterial activity. Furthermore, it has been shown that the antibacterial effects of honey depend on multiple factors including $\mathrm{H}_{2} \mathrm{O}_{2}, \mathrm{pH}$, osmotic pressure and phenolic compounds, which may act either individually or synergistically (Mandal and Mandal 2011).

\section{CONCLUSIONS}

The honey samples in this study had different concentration requirements to cause an inhibitory effect, which itself depended on the bacterium in question. The samples exhibited different relationships between temperature of thermal processing and antibacterial activity, which were generally represented by a linear or quadratic trend. The various behaviors were not dependent on the gram status of the bacteria. Only in the case of S. typhimurium did the total phenol content in the honey sample has a major effect on its antibacterial activity; inhibition of other types of tested bacteria was not dependent on the total phenol content of the honey sample.

\section{ACKNOWLEDGMENTS}

A. C. F. received partial funding from Fundação para a Ciência e a Tecnologia.

\section{REFERENCES}

ABRIL, M.V.G. and RAMIREZ, J.F. 2009. Poder antibacterial de mieles de Tetragonisca angustula valorada por concentración mínima inhibitoria. Acta Biol. Colomb. 14, 97-106. 
AJIBOLA, A., CHAMUNORWA, J.P. and ERLWANGER, K.H. 2012. Nutraceutical values of natural honey and its contribution to human health and wealth. Nutr. Metab. (Lond) 9, 61.

ALVAREZ-SUAREZ, J.M., TULIPANI, S., DÍAZ, D., ESTEVEZ, Y., ROMANDINI, S., GIAMPIERI, F. and BATTINO, M. 2010a. Antioxidant and antimicrobial capacity of several monofloral Cuban honeys and their correlation with color, polyphenol content and other chemical compounds. Food Chem. Toxicol. 48, 2490-2499.

ALVAREZ-SUAREZ, J.M., TULIPANI, S., ROMANDINI, S., BERTOLI, E. and BATTINO, M. 2010b. Contribution of honey in nutrition and human health: A review. Med.

J. Nutrition Metab. 3, 15-23.

BALTRUŠAITYTĖ, V., VENSKUTONIS, P.R. and ČEKSTERYTE், V. 2007. Radical scavenging activity of different floral origin honey and beebread phenolic extracts. Food Chem. 101, 502-514.

BOBAN, N., TONKIC, M., MODUN, D., BUDIMIR, D., MUDNIC, I., SUTLOVIC, D. and BOBAN, M. 2010. Thermally treated wine retains antibacterial effects to food-born pathogens. Food Control 21, 1161-1165.

CAMPOS-MONTIEL, R.G., PIMENTEL-GONZÁLEZ, D.J. and FIGUEIRA, A.C. 2013. Chemical and functional properties of food components. In Advances in Food Science and Technology (P.M. Visakh, T. Sabu, L.B. Iturriaga and P.D. Ribotta, eds.) pp. 151-183, John Wiley \& Sons, Inc., MA.

CUI, Z.W., SUN, L.J., CHEN, W. and SUN, D.W. 2008.

Preparation of dry honey by microwave-vacuum drying. J. Food Eng. 84, 582-590.

ERDTMAN, G. 1960. The acetolysis method. A revised description. Svensk Bot. Tidsk. 54, 561-564.

ESCRICHE, I., VISQUERT, M., CAROT, J.M., DOMENECH, E. and FITO, P. 2008. Effect of honey thermal conditions on hydroxymethylfurfural content prior to pasteurization. Food Sci. Technol. Int. 14(5 Suppl.), 29-35.

ESCRICHE, I., KADAR, M., JUAN-BORRÁS, M. and DOMENECH, E. 2014. Suitability of antioxidant capacity, flavonoids and phenolic acids for floral authentication of honey. Impact of industrial thermal treatment. Food Chem. 142, 135-143.

ESTEVINHO, L., PEREIRA, A.P., MOREIRA, L., DIAS, L.G. and PEREIRA, E. 2008. Antioxidant and antimicrobial effects of phenolic compounds extracts of Northeast Portugal honey. Food Chem. Toxicol. 46, 3774-3779.

ESCUREDO, O., SILVA, L.R., VALENTÃO, P., SEIJO, M.C. and ANDRADE, P.B. 2012. Assessing Rubus honey value: Pollen and phenolic compounds content and antibacterial capacity. Food Chem. 130, 671-678.

FUJITA, A., BORGES, K., CORREIA, R., DE MELO FRANCO, B.D.G. and GENOVESE, M.I. 2013. Impact of spouted bed drying on bioactive compounds, antimicrobial and antioxidant activities of commercial frozen pulp of camu-camu (Myrciaria dubia Mc. Vaugh). Food Res. Int. 54, 495-500.
ISLA, M.I., CRAIG, A., ORDOÑEZ, R., ZAMPINI, C., SAYAGO, J., BEDASCARRASBURE, E., ALVAREZ, A., SALOMON, V. and MALDONADO, L. 2011. Physicochemical and bioactive properties of honeys from Northwestern Argentina. LWT Food Sci. Technol. 44, 1922-1930.

JIMENEZ, M., CASTILLO, I., AZUARA, E. and BERISTAIN, C.I. 2011. Actividad antioxidante y antimicrobiana de extractos de capulín (Prunus serotina subsp capuli). Rev. Mex. Ing. Quim. 10, 29-37.

KOWALSKI, S. 2013. Changes of antioxidant activity and formation of 5-hydroxymethylfurfural in honey during thermal and microwave processing. Food Chem. 141, 1378-1382.

MANDAL, M.D. and MANDAL, S. 2011. Honey: Its medicinal property and antibacterial activity. Asian Pac. J. Trop. Biomed. $1,154-160$.

MOUSSA, A., NOUREDDINE, D., SAAD, A. and ABDELMALEK, M. 2012. Influence of temperature on the inhibitory potency of Eucalyptus honey against Candida albicans. Asian Pac. J. Trop. Dis. 2, S567-S570.

NCSS. 2007. Statistical Software, NCSS LLC.

SAGRIN, M.S. and CHONG, G.H. 2013. Effects of drying temperature on the chemical and physical properties of Musa acuminate Colla (AAA Group) leaves. Indust. Crop Prod. 45, 430-434.

SILICI, S., SAGDIC, O. and EKICI, L. 2010. Total phenolic content, antiradical, antioxidant and antimicrobial activities of Rhododendron honeys. Food Chem. 121, 238-243.

SINGLETON, V.L., ORTHOFER, R. and LAMUELA-RAVENTOS, R.M. 1999. Analysis of total phenols and other oxidation substrates and antioxidants by means of Folin-Ciocalteu reagent. Methods Enzymol. 299, 152-178.

TAORMINA, P.J., NIEMIRA, B.A. and BEUCHAT, L.R. 2001. Inhibitory activity of honey against foodborne pathogens as influenced by the presence of hydrogen peroxide and level of antioxidant power. Int. J. Food Microbiol. 69, 217-225.

TENORE, G.C., RITIENI, A., CAMPIGLIA, P. and NOVELLINO, E. 2012. Nutraceutical potential of monofloral honeys produced by the Sicilian black honeybees (Apis mellifera ssp. sicula). Food Chem. Toxicol. 50, 1955-1961.

ULUSOY, E., KOLAYLI, S. and SARIKAYA, A.O. 2010. Antioxidant and antimicrobial activity of different floral origin honeys from Turkiye. J. Food Biochem. 34(s1), 321-335.

VAIKOUSI, H., KOUTSOUMANIS, K. and BILIADERIS, C.G. 2009. Kinetic modelling of non-enzymatic browning in honey and diluted honey systems subjected to isothermal and dynamic heating protocols. J. Food Eng. 95, 541-550.

VOIDAROU, C., ALEXOPOULOS, A., PLESSAS, S., KARAPANOU, A., MANTZOURANI, I., STAVROPOULOU, E., FOTOU, K., TZORA, A., SKOUFOS, I. and BEZIRTZOGLOU, E. 2011. Antibacterial activity of different honeys against pathogenic bacteria. Anaerobe 17, 375-379. 